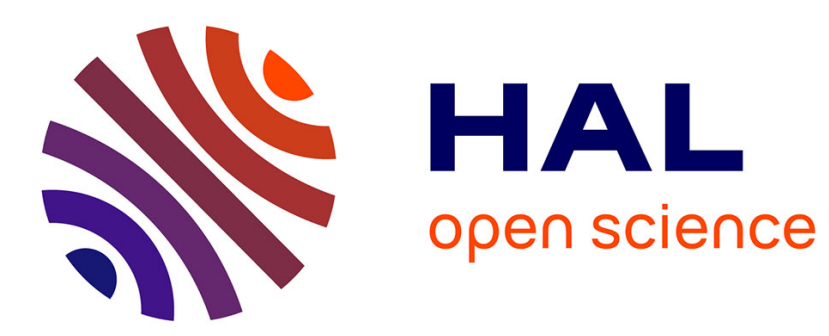

\title{
The Italian verb-noun anthroponymic compounds at the Syntax / morphology interface
}

\author{
Franck Floricic
}

\section{To cite this version:}

Franck Floricic. The Italian verb-noun anthroponymic compounds at the Syntax / morphology interface. Morphology, 2008, 18 (2), pp.167-193. hal-00669372

\section{HAL Id: hal-00669372}

\section{https://hal.science/hal-00669372}

Submitted on 14 Feb 2012

HAL is a multi-disciplinary open access archive for the deposit and dissemination of scientific research documents, whether they are published or not. The documents may come from teaching and research institutions in France or abroad, or from public or private research centers.
L'archive ouverte pluridisciplinaire HAL, est destinée au dépôt et à la diffusion de documents scientifiques de niveau recherche, publiés ou non, émanant des établissements d'enseignement et de recherche français ou étrangers, des laboratoires publics ou privés. 


\title{
The Italian Verb-Noun anthroponymic Compounds at the Syntax / Morphology Interface ${ }^{1}$
}

\author{
Floricic Franck \\ Université de Paris III-Sorbonne Nouvelle \& LPP (CNRS)
}

\begin{abstract}
This paper offers an analysis of Italian anthroponymic verb-noun compounds. It is argued that the first element of these compounds historically is an imperative $\left(2^{\text {nd }} \mathrm{sg}\right)$ form. Such a view not only accounts adequately for the evolutionary process at work in the original naming process; it also rightly accounts for the actual morphological make-up of these compounds. It is argued as well that anthroponymic compounds involving imperatives provided for a structural model which is still traceable in the morphological make-up of non-anthroponymic compounds, even though a reanalysis process has led to the reinterpretation of the verbal element of V-N compounds as a bare stem. Crucially, such a reanalysis will be said to have been favoured by the morphological unmarkedness of imperatives: as zero inflected stems, imperatives may serve as a base for paradigmatic restructuration. Italian Verb-noun compounds will be shown to offer an illustration of this basicness of the imperative, following a pattern of word formation which is available in other languages.
\end{abstract}

The liveliness of the feeling for composition manifests itself especially in the capacity of a compound to serve as model for analogical formations. If we have deduced composition from syntax, we in no way intend to assert that each single compound has taken its rise from a syntactical combination. Possibly, indeed, the greater part of the so-called compounds in the different languages are merely analogical formations modelled upon those to which in its strict sense the name compound belongs (Hermann Paul)

\section{Introduction}

The aim of this contribution is to account for the morphological properties of a sub-set of Italian verb-noun compounds, namely anthroponymic compounds of the Bevilacqua "drink the water" type, i.e. compounds whose first element is a verbal form and the noun an argument of the verb, generally a direct object. First I discuss the issue of the place and the nature of proper names in the linguistic system. Then I review some of the hypotheses put forth in order to account for the morphological make-up of the Italian verb-noun compounds. It will be argued that morphologically, the first part of many Italian V-N compounds is formally identical to the second person (sg.) imperative. This hypothesis, which will be refered to as the 'imperative hypothesis', needs no ad hoc mechanism in order to explain the final vowel of some compounds' verb forms such as bevi "drink". The originally volitional value of the compounds' verbal element will be argued to have been lost along with its formal transparency, turning this element a morphologically opaque exponent. Following Koch (1995) and Rainer (2001), it will be shown that the choice of the imperative stem in Italian is paradigmatically and structurally motivated. Once established in the system, this zero inflected stem can serve as a morphological basis due to high frequency (cf. Mańczak (2004) and (2008)),

\footnotetext{
${ }^{1}$ Many thanks to Sasha Aikhenvald, Johan Van der Auwera, Ingeborga Beszterda, Antonietta Bisetto, Denis Creissels, Alessandro Garcea, Istvan Kenesei, Jean-Léo Léonard, Thomas Lindner, Martin Maiden, Ranko Matasović, Lucia Molinu, Benedicte Nielsen, Martina Pitz, Ljiljana Progovac, Jan Radimský, Franz Rainer, Michel Roché and Aude Wirth for their comments and criticisms. My warmest acknowledgments to Prof. Witold Mańczak and Bernard Pottier for their comments, and to Mrs. Dr. Anna Bosazza (Biblioteca civica di Biella) for having made available to me some important contributions from Cesare Poma. I am also indebted to Ingo Plag and two anonymous reviewers of Morphology, whose comments and criticisms helped me to improve significantly the paper in its form as well as in its content. I remain, of course, sole responsible for the views held in this paper.
} 
formal unmarkedness ${ }^{2}$ and analogical restructuring, regardless of the semantics of the compound (cf. Maiden 2007). Not only do the anthroponymic verb-noun compounds provide support for the 'imperative hypothesis', but they also shed a new light on borderline phenomena : verb - determiner - noun compounds provide support for an analysis which sees anthroponymic compounds as a de-syntacticization phenomenon. It will be pointed out, however, that "imperative" is in Italian a category highly syncretic with other categories; no wonder, then, that researchers have been misled as to the status of the first member of Italian V-N compounds. The view that will be held in this paper is that anthroponymic verb-noun compounds originally involving imperative forms provided for a model which is still traceable in the morphological make-up of actual (non anthroponymic) Italian compounds, even though a process of reanalysis has led to the reinterpretation of the verbal element of V-N compounds as a bare stem (cf. Tekavčić (1980: 141)). Of course, reanalysis points to a dynamic and evolutionary process, but the result of reanalysis is an entity whose form is rooted in the morphological system and structurally associated with a set of forms sharing the same formal properties. From this point of view, the problem discussed indissolubly ties up synchrony and diachrony.

\section{The status of proper names}

First, I shall discuss the status of proper names and their place in the linguistic system. It is a well known fact that personal proper nouns originally point to an individual via a property, a set of properties or an event scenario prototypically associated with a given individual. Consider for example the names Pappa 'eat' and Ridi 'laugh': they can be used of individuals with whom the actions of eating or laughing are associated due to their recurrence or cognitive salience. This same cognitive salience accounts for names like Lungo 'long', Piccolo 'small', Grande 'tall' etc., which point to a physical property encoded as an adjectival form. From a Brøndalian point of view, we could analyse anthroponymic nouns as a synthesis of the $\mathbf{R}(\mathrm{d})$ type, where the Relatum represents the salient element and where the descriptive content (d) is backgrounded: in other words, the anthroponymic proper nouns fix or point to an object (R), leaving in the background the quality or the set of qualities it is made of (Brøndal (1948)). Of course, an individual can also be apprehended regardless of any characterizing property, in which case the proper name picks up a given referent or relatum via its very nomination.

It must be stressed that, unlike proper names, common names are essentially class names (cf. Collinson (1937)); for example, the phonetic string [kaza] ('home') builds a class of objects which is defined by a set of properties, and the number of objects it can be applied to depends on these properties (cf. Destutt de Tracy (1814: 102)). The extension and the comprehension are thus inversely proportional in the common name and in the proper name: while the extension is maximal and the comprehension minimal in a noun like 'thing' (that is to say, the bundle of distinctive properties of the notion of 'thing' is reduced to 'some thing' and covers a quasi infinite set of objects which can be said to be 'some thing'), the comprehension is on the contrary maximal and the extension minimal in the case of proper names: in other words, the individual who is

\footnotetext{
2 The general question of markedness cannot be addressed in this paper (for a discussion see Hjelmslev (1933) \& (1935); Jakobson (1936), Brøndal (1943), Dokulil (1958), Kuryłowicz (1964) and (1977), Mańczak (1970), Waugh (1982), Haspelmath (2006), etc.). Zero marking of imperatives is typologically widespread (cf. Bybee (1985: 173), but this feature should not occultate the fact that imperatives are "complex" in Brøndal's sense.
} 
identified by a proper name is defined by an infinite set of features and properties which set him apart from other individuals of the species, but the name points to one and only one individual: to sum up, the proper name bears a presupposition of uniqueness which is constructed as such by its very enunciation: the fact that there exist many 'Marco' or the fact that a lot of cities bear the name 'Villanova' is without any relevance for the fact that the proper name identifies in actu one object and only one. As Coseriu (1962 : 268) puts it,

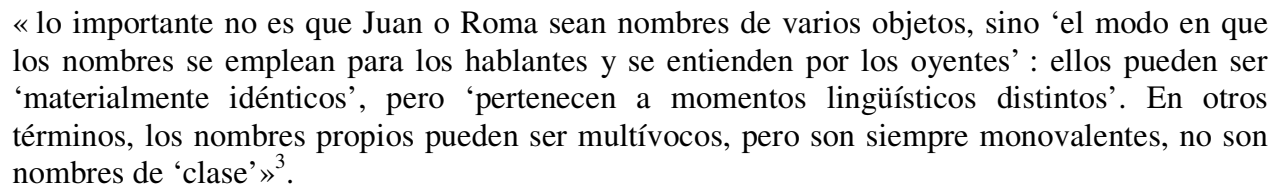

As a result, there is no possible synonymy with proper names, while it remains possible for a common name to set a list of its synonymic forms. There should not be any conceivable synonymic or antonymic expression for nouns like Giovanni or Milano, and this is due to the fact that the original bundle of properties the proper name is made of does not make part of an oppositive network of relations conveyed by the actual use of a proper name.

The last point to be mentioned concerning proper names is the fact that synchronically, the bond of anthroponymic compounds with any property or any process is semantically diluted in favour of the direct and immediate apprehension of the referent via its designation. But morphologically, I will try to show that it is possible to identify the constitutive elements of the compound, though its analysis may be obscured by a whole series of parameters: for example, the opacification of the compound-internal structure may be due to the dialectal origin of its elements: in the Veneto, we find proper nouns like Basaculo 'kiss ass' or Basadona 'kiss woman', where the phonetics of both the verbal and the nominal elements typically is that of north-east Italian dialects (cf. Rohlfs (1972: 116)).

The opacification of the compound-internal structure may also be due to a long phonetic evolution which dissolves the identity of the morphological units ${ }^{4}$ : a good example of this kind of evolution is the many variants of the name Bevilacqua 'drink the water', namely Beaqua (anno 1142), Biaqua (anno 1127), Belacqua (Dante, Purg. IV, 123), Bilaqua (anno 1535), etc. (Prati (1958: 116 note 2); Kreutzer (1967: 34)). Needless to say, it would be nonsensical to claim that all the anthroponymic compounds of a given language obey a single and unique pattern of formation. It is a wellknown fact that proper nouns like Bentivegna ('may good befall you'), Diotisalvi / Dietisalvi ('may God save you'), Diotaiuti / Dietaiuti (anno 1271 'may God help you' (Zdekauer (1896: 96sqq.)) or Bencivenne (anno 1257 'good befell us') / Bencevenne (anno 1206) / Benzevenne (anno 1227) show up with a verb form which is a ( $3^{\text {rd }}$ person sg.) subjunctive in the first three examples, and a third person (sg.) perfect indicative in the last one (cf. Federici (1907: 130, 164); Aebischer (1951: 255-256); Castellani (1956: 55sqq.); Marcato (1996: 1190)).

\footnotetext{
3 "The important thing is not that Juan or Roma be the names of various objects, but "the way the names are used by the speaker and received by the hearer: they may be 'formally identical', but they belong to distinct linguistic moments'. In other words, proper names can be plurivoque, but they are always monovalent, they are not 'class' names".

${ }^{4}$ The phonetic form of a given formant can also get opacified by such 'sporadic' phonetic changes as dissimilation or haplology : this is exactly what happened with the name Bevivino 'drink wine', whose variant Bevino has lost one syllable under adjacency constraint.
} 


\section{The morphological nature of the Verbal element}

The first question I will try to answer concerns the nature of the verbal element of the compound. I shall not review all the hypotheses which have been proposed in the history of the Romance languages, but will merely present those which seem to me more important. But first, I shall present a brief overview of Italian verb morphology.

\subsection{Brief overview of the Italian verb morphology}

The question of the Italian verb morphology is of course a very complex one and it is evident that it cannot be summed up in a few words (for recent proposals, see Maiden (1998), Thornton (1999) among others). Stated in a rather stipulative way, the Italian verb can include a verbal stem, a thematic vowel (TV), an infix or a Tense Aspect Mood (TAM) marker, an inflectional marker, and an affix. This is summed up in (1), where the various elements are ordered in a rigid way:

$$
\text { [[[[[Stem] TV] Infix / TAM] Infl] Affix] }
$$

Of course, the representation in (1) is a maximally specified one, and it is self-evident that not all the exponents need be spelled out. Take for example the present indicative of the first class verb cantare 'to sing': the $3^{\text {rd }}$ person singular indicative and the imperative $\left(2^{\text {nd }}\right.$ singular) forms are syncretic: [ [cant $\left.\left.{ }_{S t e m}\right]-a_{\mathrm{TV}}\right]$. In the case of the first person singular, the marker $-o$ seems attached as well to the right boundary of the stem: $\left[\left[\right.\right.$ cant $\left.\left._{\mathrm{Stem}}\right]-\mathrm{O}_{\mathrm{INFL}}\right]$. However, the fact that the thematic vowel and the inflectional vowel seem to occupy the same position only is an 'effet d'optique': structurally, they do not occupy the same slot, and it is only as a result of a flattening process that they do so. Instead, the structure of the $1^{\text {rst }}$ person singular shoud be $\left[\left[\right.\right.$ cant $\left.\left.\left._{\text {Stem }}\right]-\emptyset_{\mathrm{TV}}\right]-\mathrm{O}_{\mathrm{INFL}}\right]$, as opposed to $\left[\left[\right.\right.$ cant $\left.\left.\left._{\text {Stem }}\right]-\mathrm{a}_{\mathrm{TV}}\right]-\emptyset_{\mathrm{INFL}}\right]$.

Take on the other hand the verb pulire 'to clean'; in this case, the thematic vowel is available for all persons; but here there is in addition what Italian grammars view as an infix which appears in all persons except the first and second plural. Without going into the details, suffice it to say that its function has been argued to create a columnal stress, or to insure arhizotonicity accross the verb paradigm. The point to be stressed is that the infix and the TAM markers are in complementary distribution: for example, the imperfect form of pulire is pulivo in the first person singular, and we see that the Tense marker $-v$ - has usurped the place of the infix. The same can be said of the future form pulirò, where the future tense marker $-r$ - - which is nothing else than the marker found in the infinitive - fills the same slot.

I shall not enter into the details of the Italian verb morphology. Let me only add that a few verbs have several allomorphic variants: limiting myself to the present indicative, the verb andare 'to go' for example has three allomorphs: and-, va- and $v^{-} \mathrm{d}_{-}^{-5}$; and the highly suppletive verb avere 'to have' has four allomorphs: zero, $a-, a b b-$, and $a v-$. Another crucial point to be mentioned is that some morphological exponents may be involved in reanalysis phenomena: for example, the open vowel [a] that appears in the present indicative third person singular forms va (< andare ('to go')), or fa (<fare ('to do')) is not in itself a thematic vowel, but it is reanalysed as such, due to the paradigmatic pressure of $s t a, d a, f a$, and even canta, where this vowel does have this

\footnotetext{
${ }^{5}$ The verbal forms andare and fare may resort to other variants of the stem, namely $v$-and $f$-, as shown by the tuscan forms vo 'I go' and fo 'I do' which are analogically built according to the model of dare and stare (Rohlfs II, § 544: 278-279)
} 
status. This process can be representated as in (2), where the stem vowel shifts into the thematic vowel slot:

(2)

$$
\left.\left.\left[\left[\mathrm{fa}_{\mathrm{Stem}}\right]-\varnothing_{\mathrm{TV}}\right]-\varnothing_{\mathrm{INFL}}\right] \rightarrow\left[\left[\mathrm{f}_{\mathrm{Stem}}\right]-\mathrm{a}_{\mathrm{TV}}\right]-\varnothing_{\mathrm{INFL}}\right]
$$

Last, the vowels [e] and [i] (vs. [a] and [o]) share a fundamental structural property in the Italian verb morphology: both can be either an inflectional marker, or a thematic vowel: in other words, they cover the structural domain of the two morphological categories. This is particularly evident in verbs like vendere ('to sell') and dormire ('to sleep'), where there is some kind of 'chassé-croisé' between the two vowels in the present indicative and in the imperative: while $-i$ is an inflectional marker in vendi ('(you) sell') but a thematic vowel in dormi ('(you) sleep'), it is just the reverse with the vowel $-e$, which is a thematic vowel in vende ('s/he sells') but an inflectional marker in dorme ('s/he sleeps'). There is however an asymmetry between the two markers: in verbal forms like dormi, the thematic vowel [i] extends its scope over the inflectional slot, but on the other hand, the thematic vowel [e] of forms like vende does not qualify as an inflectional marker: it cannot fill the inflectional slot because the third person marker is semantically a zero, corresponding roughly to the negation of 'I' as well as of 'You', hence the redundant value of its exponent (cf. Kuryłowicz (1966-67)). Interestingly, the mid vowel [e] also appears in nouns like pane ('bread'), mare ('sea'), amore ('love'), etc... where it can be dropped in some given contexts (cf. pan di spagna ('sponge-cake'), mar nero / mediterraneo ('Black / Mediterranean Sea'), amor di patria ('love of the country'), etc.); the same holds for infinitival verbs, where the final $-e$ can be dropped in complex predicates (cf. far male ('hurt'), aprir bocca ('say a word'), prender sonno ('fall asleep'), etc...). The question whether this $-e$ should be considered an epenthetic vowel is far beyond the aim of this contribution; let us simply oberve that the vowel $-i$ in the verbal morphology is clearly endowed with the value of a second person singular marker, while it is doubtful whether $-e$ should really be considered a person marker ${ }^{6}$.

Without entering into further details, let us now review some of the most salient proposals concerning the nature of the verbal element of Italian verb-noun compounds.

\subsection{The imperative hypothesis}

It is an old idea that the Italian V-N compounds resort to the imperative and that the expression following the first part of the compound is not any kind of expression but the direct object of the verb or a modal which modifies the verb. The result is some kind of incorporation of the noun with the governing verb. For example, Fanfani (1864: 623) states that "Molti nomi che indicano o consuetudine o vizio, il popolo gli forma con la voce dell'imperativo, e col nome sostantivo per es.: Mangiafagiuoli, Rubacuori, Mozzorecchi, Commettimale, Cacadubbi, Cacaruspi, Cascamorto, Leccafrullone, Sputapane, Sputapepe, e cosí in infinito."’

One of the most influential 'defenders' of the imperative hypothesis was Diez, who clearly pointed out the syntactic origin of these compounds, hence the title of the chapter devoted to this kind of word formation: 'composition par phrase' - Satznamen

\footnotetext{
${ }^{6}$ Interestingly, it should be pointed out that the vowel [i] qualifies as an epenthetic vowel in Italian (cf. expressions such as per iscritto, per istrada, in Ispagna, per ischerzo, pissicologo, etc. (cf. Rohlfs (1966: 255ff.)).

7 « Many names expressing habits or defects are formed by people using the word in the imperative accompanied with the substantive, for instance Mangiafagiuoli, Rubacuori, Mozzorecchi, Commettimale, Cacadubbi, Cacaruspi, Cascamorto, Leccafrullone, Sputapane, Sputapepe, and so on. »
} 
in the German terminology. Diez thus analyzes the verbal element involved in the Italian compounds not as a third person singular, but as an imperative (2sg), a view that will be held by other romanists and indo-europeanists of the $\mathrm{XIX}^{\text {th }}$ and $\mathrm{XX}^{\text {th }}$ centuries. Among these, Darmesteter (1894) deserves a special mention because of its influential comparative study. I shall not present Darmesteter's in depth analysis because it is roughly the same as that of Diez's. The point to be stressed is Darmesteter's attention to the Romance verb morphology: if French doesn't allow us to identify inequivocably the nature of the first part of $\mathrm{V}-\mathrm{N}$ compounds, the morphological richness of other Romance verb systems is more likely to give us a more precise idea of the structural make-up of these compounds. Actually, for Darmesteter as well, the Italian data clearly support the imperative hypothesis. As shown in Table 1, the Italian second and third conjugations clearly distinguish the indicative and the imperative (cf. Napoli \& Vogel (1990)):

\begin{tabular}{|l|c|c|c|c|}
\hline & $1^{\text {st }} \begin{array}{c}\text { conjugation: } \\
\text { amare }\end{array}$ & $\begin{array}{c}2^{\text {nd }} \text { conjugation: } \\
\text { battere }\end{array}$ & $\begin{array}{c}3^{\text {rd }} \text { conjugation: } \\
\text { dormire }\end{array}$ & $\begin{array}{c}3^{\text {rd }} \text { conjugation: } \\
\text { pulire }\end{array}$ \\
\hline Present Indicative $(2 \mathrm{sg})$ & ami & batti & dormi & pulisci \\
\hline Present Indicative (3sg) & ama & batte & dorme & pulisce \\
\hline Imperative (2sg) & ama & batti & dormi & pulisci \\
\hline First part of V-N & ama & batti & dormi & pulisci \\
\hline
\end{tabular}

As is clear from Tableau 1, the matching between the familiar imperative form and the base used for compounding across conjugation classes is absolute. In addition to this morphological criterion, Darmesteter assumes that the verb form is endowed with a volitional value which is still transparent in proper names like Boileau, Bevilacqua, etc.

When the referent of the verb-noun compound is an inanimate object, it is assumed that an order is given to the object refered to by the compound (cf. such compounds as essuie-mains / asciugamani 'hand-towel', porte-feuille / portafogli 'wallet', etc.). In common nouns like batticuore ('heart-pounding'), for which the nominal element of the compound is the unique argument of the verb, it would have the status of a Vocative, and the noun "cuore" ('heart') would thus refer to the entity picked out and addressed in the appeal act (cf. Schulze (1868: 13); Meyer-Lübke (1895: 632)).

Although metaphoric and metonymic processes are indeed essential in language, it does not seem necessary here to posit a priori any prosopopoeia at the basis of the word formation process. All we need - and this is the position that will be held in the following paragraphs - is to assume that the imperative form traceable in anthroponymic compounds has been reanalyzed as a bare stem. In fact, the analysis of the first part of $\mathrm{V}-\mathrm{N}$ compounds as a bare stem is one of the most influential proposed in the past and has been put forth in much recent times by many authors.

\subsection{The 'verbal stem' hypothesis}

First of all, we should recall that the debate about the compound nouns was initiated in the nineteenth century, in the 'golden age' of the comparative grammar of the IndoEuropean languages, and this historical background has many consequences for the kind of analysis to which the phenomenon under examination has been subject. The verbal stem hypothesis has been argued for by Raoul Boucherie (1876: 268-270) among others, who comes round to the opinion of Friedrich August Pott: the first 
element of V-N compounds cannot be an imperative form, it is a bare stem. The first argument put forward in favour of this hypothesis is a formal one: the verbal element of $\mathrm{V}-\mathrm{N}$ compounds does not show up with any inflectional specification. It is an abstract notional entity deprived of any sign of actualization (cf. Benveniste (1966: 104)). On the other hand, a large number of inanimate objects are designated by a verb-noun compound, and we saw that it is not conceivable that an order be addressed to these objects (cf. De la Grasserie (1907: 51sqq.)). For example, no order could be given to objects like spaventapasseri 'scarecrow' or pulisciorecchi 'earpick'; hence, this semantic feature would make the 'imperative' hypothesis irrelevant (see as well Pagliaro (1930), Pisani (1933), Vogel (1993), Vogel \& Napoli (1995), Ralli (2008), etc.).

Nielsen (2002: 93) also holds the view that the first part of V-N compounds should be analyzed as a bare stem, because "(...) an imperative is totally misplaced in a nominal compound", and the same objection would apply to deverbal nouns such as battitore "batter" or portatore "carrier". We shall return later on the question of the relationship between agent nouns and V-N compounds. Let us observe for the moment that the identity between the first member of compounds and the morphological base of derived action / agent nouns is far from being absolute. The base of nouns like prevenzione ('prevention'), trattenimento ('entertainment'), contenitore ('container'), produttore ('producer'), etc. clearly is different from that of V-N compounds like previeni-infarto ('prevent-infarct'), trattieni grassi ('retain fats'), contieni documenti ('contain documents'), (birra) produci latte ((beer) 'produce milk'), and may be argued to belong to an older stratum of the morphological system (see as well the case of compounds like pettirosso ('redbreast'), capinera ('blackcap'), etc. discussed by Zamboni (1999)). Therefore it is not sure whether the same "rule" should account for these different morphological processes: the former type of compounds is much more akin to a syntactic construct than the just mentioned derived nouns, though of course the major part of compounds doesn't show anymore any connection with their syntactic source, thus illustrating a morphologization process which may turn a syntactic unit into a morphological stem.

Actually, it seems that the verbal stem analysis of V-N compounds is due to an inaccurate analysis of the formal properties of its first element and to a misunderstanding concerning the role of semantics. Concerning the first point, Darmesteter (1894: 185-186, footnote 2) rightly observes that Boucherie's "verbal stem" analysis unsufficiently pays attention to the Italian second conjugation whose thematic vowel is $-e$, while the final vowel of the first element of V-N compounds is $-i$ (see Tableau 1 above). This is even more problematic for the third conjugation verbs endowed with affix -isc- : a form like pul-isc-i ('clean') cannot be said to be a "bare stem", unless we deprive of any relevance the notion "verb stem".

As far as semantics is concerned, it must of course be taken into account in order to decide whether some phonetic string must be considered a compound or not. But it should be born in mind that the semantic unity of a compound is a matter of gradience, and that it is only the final point of a long semantic and morphosyntactic process which turns two independent entities into one (cf. Daneš (1966)). In this context, we should keep in mind the crucial observation of Brugmann (1886/1972: 4-5), according to whom "no hard and fast line can be drawn between a phrase or group of words connected in some syntactical relation, and a compound 8 . Moreover, it has long been

\footnotetext{
${ }^{8}$ See also Paul (1891: 371ff.).
} 
recognized that the semantic content of the compound elements, and especially their semantic relationship, show a great deal of variation and that it cannot be predicted $a$ priori: everything shows that this kind of relationship is highly underspecified (cf. Coseriu (1981: 5ff.)). Therefore, although semantics must of course be taken into account, it is not certain whether semantics must be regarded as the chief criterion for the identification of the morphological nature of the compound elements.

To take a wellknown example, the first element surfacing in (at least some) French ment adverbials clearly shows up as the relic of an old gender specification: craintivement ('timorously'), fraîchement ('freshly'), ouvertement ('openly'), honteusement ('shamefully'), etc. As a matter of fact, it would be non-sensical to claim that the connection with the corresponding feminine adjectives is purely casual; but at the same time, there is no reason synchronically to assign any semantic motivation to the choice of a surface form which is basically feminine. In theses cases, it can be said that the feminine variant of the adjective has acquired the status of a purely morphological base for derivation. To use Kuryłowicz' (1977: 10) crucial distinction, the structural basis ("fondement structural") for derivation is the feminine, though of course the masculine semantically is basic ("fondement sémantique"). It may be noted that the hypothesis to be discussed in the next section is likewise rooted in semantics.

\subsection{Agent nouns and V-N compounds: Bisetto (1999)}

An interesting hypothesis put forth by Bisetto (1999) is that Italian V-N compounds are in fact N-N compounds whose first element is an agent noun of the -tore type. As a matter of fact, a compound like rompiscatole "nuisance" may allow an interpretation very close to that of the phrase rompitore di scatole. The compound noun would thus have the structure V[+tore] N, with the suffix -tore deleted (cf. Bisetto (1999)). For lack of space, this hypothesis cannot be discussed in detail. In its spirit however, this hypothesis is not very different from that of Graffi's (1996), who posits an "empty suffix" in order to explain the imperative morphology of -ere verb class.

It has been pointed out by one of the reviewers that Bisetto's analysis may be excluded for those verbs that appear in V-N compounds but do not allow semantically the -tore suffixation. Though we didn't find such examples, we may mention V-adv compounds like Vaipiano ('go slow') or Faibene ('do well'), for which there doesn't seem to be corresponding agent nouns (cf. *Va(i)tore), or for which the agent noun would select another morphological base (cf. andatore "goer", facitore / fattore "maker"). Conversely, we may observe that many -tore agent nouns are attested without any V-N counterpart: this is the case of sciatore "skier" ( $<$ sciare), or dormitore "sleeper" ( $<$ dormire) among others. More crucially, as pointed out earlier, it is noteworthy that the stressed syllable of agent nouns like tenitore "holder" doesn't show the diphthongization of the tonic vowel, while such diphthongization is observed in compounds such as (porta) tienitutto ((door) hold everything). The same observation holds for many other compounds such as sostieniseno "brassière", where the verbal form cleary is different from the base of the agent noun sostenitore "upholder" (cf. Rainer (2001: 390)). From a syntactic point of view, if we consider that a compound noun like rompiscatole is derived from the phrase rompitore di scatole, we should assume that deletion involves not only the agent suffix, but also the preposition.

Needless to say, more serious arguments should be adduced as evidence of the fact that such a cascade of deletions is involved in the formation of the compound. On more general grounds, the main question to be asked is whether we need to assume the existence of a suffix (be it empty or not), in order to explain the shape of the first 
element of V-N compounds. In our view, such a suffix is not necessary, nor is it economic. Furthermore, it will fail to account for the case of action nouns like rompimento ('breaking'), where we can hardly postulate the existence of -tore before the suffix -mento.

\subsection{The '3rd person' (singular present indicative) hypothesis}

The semantic structure of compounds has led various researchers to state that the morphological basis for verb-noun compounds is neither the imperative, nor the bare stem, but the third person of the present indicative. This is for example the opinion of Cesare Poma (1914: 7) concerning compound proper names ${ }^{9}$. As a matter of fact, Cesare Poma states that putting aside augurative compounds, most surname compounds can be taken to involve the ( $3^{\text {rd }} \mathrm{sg}$.) present indicative as a base, not the imperative, in as much as they result from an habitual action. In other words, given that proper names refer to some property or to a set of properties typically associated with a given individual, we would expect these properties to be permanent ones or at least recurrent ones; hence the verbal form of anthroponymic compounds should be a third person singular of the present indicative. Once again, the choice of the third person indicative as the morphological unit involved in verb-noun compounds is not made on morphological grounds, but on semantic ones: more specifically, the identification of the morphological unit is inferred from the semantic paraphrase of the compound: for example, from a name like Mazzagalli ('kill-cocks'), it will be inferred that it is built on the present indicative stem, only because of the paraphrase 'the one who kills cocks'. The problem is that this paraphrase is only one among many others. Therefore there is no reason a priori to favour this reading. Furthermore, if we take into account the morphological make-up of the verbal component, it must be recognized that the third person hypothesis has to face various questions: in compounds like Vinciguerra / Vinciguerre "win war(s)" (anno 1208 (Santini (1895: 171)), we find a verbal form of the second conjugation whose third person singular is vince in the present indicative, and not vinci. This does not mean, of course, that proper nouns like Vinceguerra are not attested: indeed they are attested, but they are much less frequent than the Vinciguerra type; furthermore, in Old Tuscan, $-e$ was indeed the normal ending for $2 \mathrm{sg}$. imperatives (except Florentine which had the $-i$ ending (Castellani (1956: 66)); thus the form vince per se does not invalidate the imperative hypothesis.

In order to explain the Vinciguerra type, few solutions are available: take either the bare stem or the third person singular form, that is to say vince, and write a two-step rule of deletion / insertion, or invoke a Vowel Raising Rule, in the spirit of Vogel (1993) and Vogel \& Napoli (1995) ${ }^{10}$. Needless to say, this kind of rule is a purely ad hoc device we can easily dispense with if we accept the idea that a) first, the morphological make-up of an expression can be the result of rules that are no longer active in the present stage of the language; in other words, certain configurations can be interpreted as the frozen relic of previously active rules and schemata; b) second, a given structural pattern can be activated and produce series of paradigms regardless of the semantic value of the involved items: that is to say, once established in the system, a given pattern can spread over series, and its extension can be such that it opacifies the

\footnotetext{
${ }^{9}$ As predecessors of the third person (singular present indicative) we can mention Meunier (1875) and Butet (1801).

${ }^{10}$ It could be argued as well, as suggested by one of the reviewers, that the final vowel of the first element of the compound is epenthetic. This solution doesn't seem to us economic; more importantly, it has the undesirable drawback to lead to the conclusion that the relationship between the verb forms and the first element of these compounds is purely casual.
} 
initial semantic motivation underlying the pattern. This in turn implies a relaxing of the strict correspondence between semantic and morphological information (cf. on this point Maiden (2007)). As Rainer (2001: 390-391) puts it, « the simplest statement about the form of the first element of the (italian) verb-noun compounds would thus be that it is borrowed from the informal singular imperative. Few linguists who have tackled this problem over the last few years, however, have resorted to this simple solution (see, however, Thornton 1990: 179). The reason is the - generally tacit - assumption that form and function have to be perfectly isomorphic in word-formation. (...)».

From our point of view, this is precisely what holds with the Italian verb-noun compounds. Thus, we shall see that the imperative hypothesis rightly accounts for the morphological make-up of the Italian verb-noun compounds, provided we realize that the initial stage of its development may be no longer transparent in the modern language, where it appears as frozen, especially in non anthroponymic compounds.

\section{Aspects of the 'Imperative hypothesis'}

Before reviewing the positive arguments in favour of the 'Imperative hypothesis', let me first give a few indications concerning the morphological properties of the $2 \mathrm{sg}$. imperatives. It is a well known fact that crosslinguistically, one of its most salient morphological properties is the absence of any TAM and person features. Thus very often, the Imperative is a bare stem, and when it is not a bare stem, it bears very few morphological specifications (cf. Pott (1859: 613)). When the imperatives do bear some specifications, these are not infrequently the same as that of the present indicative (cf. Floricic (2007)): as a matter of fact, we have in both cases a minimally specified form which is morphologically unmarked.

The analogy between the present indicative and the imperative goes even farther: in some languages, the forms of the imperative overlap with the paradigm of the present indicative, a point which is perfectly understandable, if we bear in mind that an order can be executed only in the temporal interval which opens at the zero point of the speech act (cf. Kurylowicz (1964)). Now, if we turn back to the morphological features of the imperative, we can give it a representation which corresponds roughly to what we have in (3), where [M] stands for the verbal stem, [f] for the thematic vowel slot, the first $\emptyset$ for the absence of TAM specifications, and the last one for the absence of person specification:

(3)

$\left[\left[\mathrm{M}_{\text {STEM }}\right]\left[\mathrm{f}_{\mathrm{TV}}\right]\left[\varnothing_{\mathrm{TAM}}\right]\left[\varnothing_{\mathrm{P}}\right]\right]=$ The imperative is a form endowed with an empty morph (the thematic vowel (cf. Hockett (1947: 337)), but without person specifications, nor TAM markers

If we take a form like the imperative canta from cantare ('to sing'), the representation will be something like (4): cant- is the verbal stem, - $a$ the thematic vowel, and the two zeroes stand for the lack of TAM and person / number features (cf. Lemaréchal (1997)). Incidentally, it may be noted that there is a morphological correspondence between the third person sg. of the present indicative, and the second person of the imperative.

(4)

$$
\left[\left[\operatorname{kant}_{\mathrm{STEM}}\right]\left[-\mathrm{a}_{\mathrm{TV}}\right]\left[\varnothing_{\mathrm{TAM}}\right]\left[\varnothing_{\mathrm{P}}\right]\right]
$$

The link between the present indicative and the second person imperative is more transparent in verbs like pulire ('to clean'), where the bare stem is puli-, while the present indicative and the imperative both show up with the reflex of the Latin infix 
$-s c-$., plus the second person singular marker $-i$ :, hence pulisci, whose representation is given in $(5)^{11}$ :

(5)

$$
\begin{aligned}
& {\left[\left[\operatorname{pul}_{\text {STEM }}\right] \quad\left[-i_{\mathrm{TV}}\right]\right.} \\
& \text { I } \\
& \left.\left[- \text { isc- }_{\text {Infix }}\right]\left[\varnothing_{\text {TAM }}\right]\left[-i_{P}\right]\right]
\end{aligned}
$$

Of course, the same can be said about verbs like vendere ('to sell'), whose third person singular of the present indicative and whose bare stem is vende, while the imperative is vendi. In this case too, the second person ( $\mathrm{sg}$ ) of the imperative is formally syncretic with the second person (sg) of the present indicative:

(6)

$$
\left[\left[\operatorname{vend}_{\mathrm{STEM}}\right]\left[\varnothing_{\mathrm{TV}}\right]\left[\varnothing_{\mathrm{TAM}}\right]\left[-\mathrm{i}_{\mathrm{P}}\right]\right]
$$

As shown in (6), the slots of the TAM marker and of the thematic vowel being empty, it can be filled by the inflectional marker, thus providing the structural position immediately on the right of the verb stem with the person exponent. Now, these two classes of verbs are crucial for the demonstration that the morphological entity involved in verb-noun compounds is not a bare stem (contra Vogel \& Napoli (1995)), but an inflected form reanalysed as a bare morphological unit. It is precisely these classes of verbs which have led some comparativists to the conclusion that the verbal element of verb-noun compounds indeed is an imperative. Let us now review the main points of this hypothesis.

\subsection{The 'freezing' of a syntactic construct}

It has long been recognized that frequency of use and routinization processes can lead from free syntax to compound or derived forms; one of the most striking examples is that of -mente adverbs, which arose from the crystallization of an adjective plus the noun mente 'mind' (cf. Lehmann (2002)). Apart from this well known example, we have whole series of adverbs and pronouns which arose from the fusion of free forms through routinization and "mechanization", to use the expression of Wegener (1883): think of the French indefinite pronouns quelqu'un ('someone'), quelque chose ('something'), quelconque ('any'), chacun ('each one'), etc. and of adverbs like toujours ('always'), pourtant ('nevertheless'), longtemps ('(for) a long time'), parfois ('sometime'), partout ('everywhere'), aujourd'hui ('today'), etc... From this point of view, and despite Corbin (1992) and (1997), the case of the anthroponymic verb-noun compounds only is one of many examples of this fundamental process of lexicalization

\footnotetext{
${ }^{11}$ The aim of the representation in (5) is to account for the ambivalent status of the vowel [i]: at the same time thematic vowel and part of the infix, showing thus a kind of structure which is reminiscent of coalescence. According to Ricca (2008) corpus study, -isci- VN compounds would be unproductive in Italian. Interestingly, some V-N compounds involving verbs of the pulire ("to clean") type show some variation within a stem-like and an imperative-like formant: for instance, pulimano ('hand towel') is found alongside with puliscimano, hence showing some kind of allomorphy of the verb stem. However, this kind of allomorphy only is available for a small class of compounds, and the selection of the pulimano variant probably is phonologically-driven, in so far as [puli], as a syllabic trochee, satisfies some kind of Foot binarity constraint: many other examples could be adduced to illustrate this preference for bisyllabic verb bases (for other examples see Thornton (2007: 254ff.)). According to Ralli (2008), the compound-internal vowel would be (on the way to become) a compound marker. Though appealing, this hypothesis still has to explain the presence of the -isc-infix which surfaces in the puliscimano type compounds.
} 
(cf. Bally (1922: 6); (1944: 148); Bauer (1978); Lehmann (2004); Sauer (2004), etc.), a process which is evolutive / dynamic in nature and which does not allow any clearcut separation between a group of individual words and a single word formed with various free / bound forms (cf. Daneš (1966) and (1971)).

\subsection{The arguments in favour of the Imperative hypothesis}

If common nouns do not provide us with any clear evidence for the syntactic origin of verb-noun compounds, the anthroponymic ones do support the original syntactic nature of these compounds. One of the first researchers who investigated the Italian anthroponymic verb-noun compounds is Flechia (1877-78), who points out a crucial property of these Italian compounds: first, they display a verbal form which is morphologically a second person singular imperative, and we saw in the preceding paragraphs that one of its most salient properties is its being zero inflected or minimally inflected $^{12}$. Second, when the noun fulfils the function of direct object, it can appear with an initial consonant which seems to be at first glance that of the determiner: the examples of Flechia are Batti-l'-oro ('beat-the-gold'), Becca-l'-osso (peck-the-bone'), Bevi-l'-acqua ('drink-the-water'), Caccia-l'-oste ('hunt-the-army'), Canta-la-messa ('sing-the-mass'), Fa'-l'-immagini ('make-the-images'), Fa-la-guerra ('make-thewar'), Fa-l'-orso ('make-the-bear'), Guazza-l'-otri' ${ }^{13}$, Guida-l'-oste ('guide-the-army'), Mazza-l'-orso ('kill-the-bear'), Mazza-l'-omo ('kill-the-man'), Pitta-l'-uga / Picca-l'uga ('peck-the-grapes'), Salva-l'-anima ('save-the-soul'), Spezza-l'-asta (/ Spessal'asta 'break-the-lance'), Taglia-la-tela ('cut-the-cloth'), Taglia-'l-melo ('cut the appletree'), and it is possible to mention many other nouns of this kind.

Now, the first question to be raised concerns the nature of the initial consonant of the object noun: is it an epenthetic consonant, or is it a definite determiner?

\subsubsection{The $\mathrm{V}-l(\mathrm{v})-\mathrm{N}$ compounds: determiner or epenthetic consonant?}

It is rather striking that many anthroponymic verb-noun compounds are provided with a consonant when the noun has an initial vowel: for example Batti-l'-oro, Becca-l'osso, Bevi-l'-acqua, Caccia-l'-oste, Fa'-l'-immagini, etc, hence the question as to whether this consonant must be viewed as an epenthetic segment inserted in order to avoid hiatus. As is clear from our examples however, we can mention many compounds where the consonant do not solve any hiatus: such examples are Canta-la-messa or Fala-guerra, where the string LA (vs. LO, LE, etc.) is selected because the following noun is feminine; from this point of view, this string is nothing else than the definite article (cf. Marcato (1996)). Furthermore, in other cases, the inserted consonant complexifies the syllabic structure of the compound: in forms like Taglia-l-melo ('cut the apple-tree'), Abbatti-l-toro ('kill the bull' (Poma (1914: 7))) or Premi-l-cuore ('press-the-heart') / Premi-l-core ${ }^{14}$ (Skok (1911: 46); Kreutzer (1967: 140)), the consonant provides the verb final syllable with a coda, a point which would be unexplainable on phonological grounds. As a consequence, it is clear that these

\footnotetext{
${ }^{12}$ It is evident that the first element of V-N compounds doesn't surface with the intonational contour of the imperative, nor does the verbal form refer to a process expected to be executed by an agent.

${ }^{13}$ See as well Guazzagliotri, Guazzalotti, Guizzaliotri (< Guazalotis), etc (cf. Poma (1910: 16)).

${ }^{14}$ The noun Premilcore / Premilcuore is an example in point of the complexity of these compounds. The expressions Castro Plano Mercurii and Plamercorio are mentioned in old charts of the XII ${ }^{\text {th }}$ century. In the following times, the name changes into Premalcorio and Primalcore: a remotivation process would thus have led to the actual form Premilcuore (cf. Sauer (2004)). Needless to say, for such a process to have taken place, the pattern it is modeled on must have been salient enough to give rise to this very designation.
} 
compounds contain a noun with a determiner, and it is clear as well that these compounds invalidate the common assumption according to which verb-noun compounds are built on uninflected abstract entities, such as the verbal or the nominal stem $^{15}$ : many anthroponymic compounds involve morphological entities which are not unspecified, and which show up with both morphological and syntactical specifications. In other words, the noun in the examples mentioned above is not a virtual notion, but an actualized entity.

The point to bear in mind is that not all anthroponymic compounds obey the same principle of formation, and more importantly, not all the anthroponymic compounds are created at the same moment of the language evolutionary process, or in the same linguistic community. It follows that we have a first stratum of formations in which the imperative is quite transparent morphologically and semantically, and secondary strata of analogical formations. Take for example the name Prendilacqua ('take the water'): morphologically, the first element of the noun cannot be a verbal stem because, as we just saw, the verbal stem would be prende, which corresponds to the third singular present indicative. Semantically, the present indicative hypothesis doesn't seem to work, because in this case, the original sentence would have had a descriptive / constative value that it cannot have: in other words, a sentence like 'you take the water' can hardly describe an actual state of affairs, because of the second person marker on the verb. The only available interpretation is a volitive one, that is an interpretation in which the verb expresses an order or a wish directed to the addressee. But of course, from the fact that many anthroponymic verb-noun compounds involve an imperative in the naming process of a given referent, it does not follow that all the verb-noun compounds, in all the periods of the history of language are created in such a way. All we need is to assume that an extension or spreading process took place, and that the anthroponymic compounds form one of the starting points of this extension process (cf. Prati (op. cit.); Lindner (2003), (2005)). Now, the question is: what are the structural conditions which have favoured the choice of the imperative in compounds where semantically there is no reason to select this form? In other words, in all the non anthroponymic compounds where there doesn't seem to be any volitive dimension as well as in the compounds referring to inanimate objects, what would be the reason or the impulse for choosing the imperative as a stem?

\subsection{2. 'Holes in the pattern' and reanalysis}

In order to answer these questions, it should be remembered that the informal imperative often is a form endowed with an empty morph - the thematic vowel - but without person specifications, nor TAM markers. We should also bear in mind that within the most productive Italian verb class (cf. (8)), the stem is endowed with a thematic vowel but no personal ending:

(8)

$$
\left[\left[\mathrm{kant}_{\mathrm{STEM}}\right]\left[-\mathrm{a}_{\mathrm{TV}}\right]\left[\varnothing_{\mathrm{TAM}}\right]\left[\varnothing_{\mathrm{P}}\right]\right]
$$

\footnotetext{
${ }^{15}$ Verb-determiner-Noun compounds are mainly found outside the core of the lexical stock of the language (i.e. in Toponyms, Zoonyms, Anthroponyms, etc). However, some of these compounds can also be found in Italian common names (see battiloro 'gold-beater', strizzalocchio 'wink', etc. (cf. Ricca (2005: 480, fn. 16)), showing evident violations of such "rules" or "constraints" as the No Phrase Constraint (i.e. words are built on a base of words and bound morphemes, not on phrases) or the Generalized Lexicalist Hypothesis (i.e. No syntactic rule can refer to elements of morphological structure (cf. Botha (1983) and Lapointe (1980)).
} 
Given the saliency and productivity of this verb class and given that the only exponent after the verb stem is a thematic vowel, it is not difficult for an imperative form like prendi "take!" to be reanalysed as a stem containing no person marker but containing a thematic vowel ${ }^{16}$. Interestingly, among the Verb-Noun compounds contained in the GRADIT, $81,4 \%$ are found in the most productive verb class in -are, while the verbs in -ere / -ire serve as basis of the remaining 18,6\% (cf. Ricca (2005: 470-471)). Thus, for a verbal form like prendi, we would have the process described in (9):

(9)

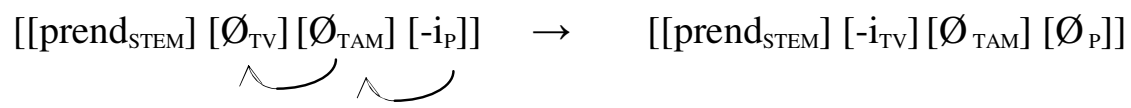

In the case of V-N compounds, it could be assumed that reanalysis has turned an imperative form into a morphomic unit, that is, a purely morphological entity void of any specific semantic content (Aronoff (1994: 25)). The notion of morphome may however occultate the crucial fact that we are dealing with a process - reanalysis which is fundamentally evolutive in nature, and the "morphomic" stage only is the end point of this process. As a matter of fact, it can be recalled with Koch (1995: 60sqq.) that morphological paradigms can be restructured on the basis of the imperative $(2 \mathrm{~d} \mathrm{sg}$.) taken as a stem. The example of the verb ed- "eat" in Attic Greek would offer an illustration of such a restructuring based on the morphological zero associated with imperatives (see Pisani (1933: 260)):

\section{Imperative}

Present $1 \mathrm{Sg}$

Present $2 \mathrm{Sg}$

Present $3 \mathrm{Sg}$

Infinitive

Future $1 \mathrm{Sg}$

(Koch (1995: 60))

$\begin{array}{ll}\text { Homeric } & \text { Attic } \\ \text { es-thi “eat!" } & \text { esthi-e } \\ \text { ed-ō } & \text { esthi-ō } \\ \text { ed-eis } & \text { esthi-eis } \\ \text { ed-ei } & \text { esthi-ei } \\ \text { ed-menai } & \text { esthi-ein } \\ \text { ed-o-mai } & \text { ed-o-mai }\end{array}$

The paradigm in (10) clearly shows that the Attic Greek verb paradigm was created using the imperative inflected form (esthi) as a zero-inflected stem (esthi- $\varnothing$ ), following a path reminiscent of that involving the third person (sg.) perfect forms in Spanish and Occitan (cf. Bybee et Brewer (1980: 210) $)^{17}$. The same kind of reanalysis can be said to have turned the Italian imperative $\left(2^{\text {nd }} \mathrm{sg}\right)$ into a stem, thus obscurating the initial

\footnotetext{
${ }^{16}$ It should be recalled that a similar process of reanalysis holds with verbs like fare (< lat. facĕre), where the vowel $-a$ - has been reanalyzed as a thematic vowel, while the original thematic vowel is $-e-$. The structural proximity between the imperative (2sg.) and the stem also explains why plural forms do not seem to be allowed as first member of V-N compounds: as marked forms, plurals are not likely to form an optimal base for word formation. Moreover, if we assume that anthroponymic V-N compounds arise as the cristallization of a given scenario or state of affairs prototypically associated with a given individual, we shall not expect this scenario or this state of affairs to apply jointly to a set of individuals, nor shall we expect the notion or entity refered to by the noun to be undiscriminatingly picked out by an indefinite article (cf. *Beviunaqua vs. Bevilacqua, *Battiunoro vs. Battiloro, *Alzaunpede vs. Alzalpede, * Dormaunfuoco vs. Dormalfuoco, etc.)).

${ }^{17}$ In the case of Spanish and Occitan, it is assumed that reanalysis crucially relies on frequency effects (Bybee \& Brewer (1980: 226-227)), in so far as the perfect would seem to show the highest frequency rate after the present indicative. As for imperatives, it is not sure whether frequency should be viewed as the "déclencheur" of reanalysis. Koch (op. cit.) points out that early acquisition of the imperative, coupled with high frequency of certain verb forms, may well be responsible for its reanalysis as a stem on which morphological innovations may be built (cf. as well Maiden (2007)).
} 
motivation underlying the old V-N anthroponymic compounds. As Tekavčić (1980: 141) puts it, there is no doubt that we are dealing with an original imperative form whose volitional value has been lost with time, so that «(...) l'elemento verbale viene oggi sentito come un tema verbale non attualizzato, in cui le desinenze sono un resto dello status primario » ("the verbal element is felt today as a non actualized verb stem whose inflectional markers are a relic of the old primary status" (see as well Prati (1958:102)).

In addition, we saw before that when we compare Italian verb morphology with Latin, we immediately notice a very important difference: as shown in (11), the Latin verbal forms have a thematic vowel thorough the whole paradigm, while this is not the case in Italian, where the thematic structure of the verb is at best defective ${ }^{18}$ :

\section{Latin verbal structure}

\begin{tabular}{|c|c|c|c|c|c|}
\hline stem & $\begin{array}{c}\text { TV } \\
\text { am-ā-re }\end{array}$ & infl. & stem & $\begin{array}{c}\text { TV } \\
\text { tim-ē-re }\end{array}$ & infl. \\
\hline am- & $-\varnothing-$ & $-\overline{\mathrm{O}}$ & tim- & $-\mathbf{e}-$ & $-\overline{\mathrm{O}}$ \\
\hline am- & $-\overline{\mathbf{a}}-$ & $-S$ & tim- & $-\overline{\mathbf{e}}-$ & $-S$ \\
\hline am- & $-\check{\mathbf{a}}-$ & $-\mathrm{t}$ & tim- & -ё- & $-s$ \\
\hline am- & $-\overline{\mathbf{a}}-$ & -mŭs & tim- & $-\overline{\mathbf{e}}-$ & 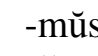 \\
\hline am- & $-\overline{\mathbf{a}}-$ & -tı̌s & tim- & $-\overline{\mathbf{e}}-$ & -tı̌s \\
\hline am- & $-\mathbf{a}-$ & $-n t$ & tim- & $-\mathbf{e}-$ & $-n t$ \\
\hline stem & $\begin{array}{c}\text { TV } \\
\text { leg-e-re }\end{array}$ & infl. & stem & $\begin{array}{c}\text { TV } \\
\text { d-ă-re }\end{array}$ & infl. \\
\hline leg- & $-\varnothing-$ & $-\overline{0}$ & d- & $-\varnothing-$ & $-\overline{0}$ \\
\hline leg- & $-i-$ & $-s$ & d- & $-\overline{\mathbf{a}}-$ & $-S$ \\
\hline leg- & $-i-$ & $-t$ & d- & $-\breve{a}-$ & $-t$ \\
\hline leg- & $-\mathrm{i}-$ & -mŭs & d- & $-\breve{\mathbf{a}}-$ & -mŭs \\
\hline leg- & $-i-$ & -ť̃s & d- & $-\breve{a}-$ & -tîs \\
\hline leg- & $-\mathrm{u}-$ & $-n t$ & d- & $-\breve{\mathbf{a}}-$ & $-n t$ \\
\hline stem & $\begin{array}{c}\text { TV } \\
\text { aud-ī-re }\end{array}$ & infl. & stem & $\begin{array}{c}\text { TV } \\
\text { cap-ĕ-re }\end{array}$ & infl. \\
\hline aud- & $-\mathrm{i}-$ & $-\overline{0}$ & cap- & -i- & $-\overline{0}$ \\
\hline aud- & $-\overline{1}-$ & $-s$ & cap- & $-\breve{1}-$ & $-S$ \\
\hline aud- & $-\breve{1}-$ & $-\mathrm{t}$ & cap- & $-\breve{1}-$ & $-\mathrm{t}$ \\
\hline
\end{tabular}

${ }^{18}$ To take just two examples, the present Indicative of verb forms like vendere ('to sell') and cantare ('to sing') shows up with a thematic vowel which respectively surfaces in 2 and 3 of the six forms of the paradigm :

\begin{tabular}{llll}
\multicolumn{5}{c}{ vendere } & \\
stem & TV & infl. & affix \\
vend & $-\varnothing$ & - o & \\
vend & $-\varnothing$ & $-\mathrm{i}$ & \\
vend & $-\mathrm{e}$ & $-\varnothing$ & \\
vend & $-\varnothing$ & - iamo & \\
vend & $-\mathrm{e}$ & - te & \\
vend & $-\varnothing$ & - o- & - no
\end{tabular}

\begin{tabular}{llll}
\multicolumn{5}{c}{ cantare } & \\
stem & TV & infl. & affix \\
cant & $-\varnothing$ & - o & \\
cant & $-\varnothing$ & $-\mathrm{i}$ & \\
cant & $-\mathrm{a}$ & $-\varnothing$ & \\
cant & $-\varnothing$ & - iamo & \\
cant & $-\mathrm{a}$ & $-\mathrm{te}$ & \\
cant & $-\mathrm{a}$ & $-\varnothing$ & - no
\end{tabular}

We shall take the plural ending -no to be an affix attached to the right-hand boundary of vend-o and cant$a$ (for a discussion, see Spagnoletti \& Dominicy (1992)). 


\begin{tabular}{|c|c|c|c|}
\hline aud- & -mŭs & cap- & $-\breve{1}^{-}$ \\
\hline aud- & -tǐs & cap- & $-\breve{1}-$ \\
\hline aud- & -unt & cap- & $-\mathrm{i}-$ \\
\hline
\end{tabular}

The point is that the rise of the imperative as a base for compounding is morphologically grounded, although, of course, the morphology is not the whole story. As Lloyd (1966: 260-261) pointed out, it is a structural hole in the word formation system at its initial stage that has been filled by expressive formations involving the imperative as a base. The other salient fact is that the morphological grounding of verbnoun compounds implies a relative degree of idiosyncrasy: that is to say, the choice of the imperative as a stem is at least in part governed by the nature of the Italian verbal system and by its particular evolution from Latin. In turn, this implies that what is valid for Italian may not be so for other Romance languages, merely because of the languagespecific anchoring of the verbal morphology (cf. Rainer (2001: 390-391)) ${ }^{19}$ : see for example the question of stress, the question of thematic vowels, the question of infixal elements, etc. As is well known, many morphological phenomena are prosodicallyconditioned, and of course, the prosodic conditions on morphological structure are highly language specific.

Now, there is a last point to be investigated, namely, the nature and characteristics of the naming process as such and the question of endo-exocentricity.

\subsection{Naming process and the endo- / exocentricity question}

Any object or individual can be identified via different naming processes. As noted above, entities or objects may be identified via the designation of properties or qualities (originally) associated with a given individual; we have mentioned earlier proper names like Lungo 'long', Piccolo 'little', Grande 'tall', Biondi 'blond', Bruni 'brown', etc., with a clearly adjectival origin, originating as qualifications of a given individual. There is also a set of entities or objects, which are identified via the designation of a phenomenon or process which takes place in a recurrent way, or which is prototypically associated with some individual or object. For example, an object used for opening the mouth can be named apribocca 'open mouth', and the two elements of the compound respectively refer to the process, and to the object affected by it, in a prototypical situation. But of course, as a name identifying a given referent, apribocca is not a name of process but a name of object, and the scenario it involves, only is part of its semantic instruction (that is to say, 'something which is used to open the mouth'). As a consequence, the name apribocca is of course not to be analysed as an order given to an object, nor as a description of an event; but morphologically, the verbal element of the compound is but an imperative form used and reanalyzed as an uninflected stem.

\footnotetext{
${ }^{19}$ Koenig (1953: 14) observes that "there are no spanish names corresponding to the widely distributed French and Italian forms Boileau, Bevilacqua, Taillefer, Tagliaferro, Boivin, etc." It is of course outside the scope of this paper to discuss the question of Spanish anthroponyms. Though Spanish seems to resort mainly to the third person singular (present indicative) in V-N compounds (cf. Rainer (op. cit.)), it is worth pointing out that like other Romance languages, Spanish has V-V compounds whose elements has been recognized (since at least Nebrija (1492)) as conjoined imperatives: vaivén 'sway, coming and going', quitaipón / quitapón 'pompon', correveidile / correvedile ('gossip, go-between'), etc. (cf. Darmesteter (1894: 177); Colón Doménech (2002)). Interestingly, these V-V compounds appear as well as proper nouns, with or without conjunction (cf. the Tuscan name Tallamanduca ('cut-eat'), anno 1208 (Santini (1895: 151)), or the Sardinian coordinative compound Cok'-e-mandica ('cook-and-eat') found in the Condaghe di San Pietro di Silki (cf. Delogu (1997: 126-127), Paulis (1997: 165))).
} 
Of course, the same can be said of whole series of compounds like prenditutto 'take everything' or tienitutto 'keep everything', which are constructed according to a wellestablished structural schema. Now, this also applies to anthroponymic compounds; as personal names, we can imagine proper nouns like Apripancia 'open stomach' or Tienimano 'keep hand', where the final vowel of apri, and the diphthongization of the tonic vowel of tieni clearly show that we are dealing with imperative forms, and not with bare stems or abstract morphological entities such as "lexemes" (pace Villoing (2000), (2003a-b), Kerleroux (2004) and others) ${ }^{20}$. Names like Stammibene "feel good" are particularly interesting, in so far as they show up with the $1^{\text {rst }}$ person (singular) enclitic object $m i$, a feature we can easily account for if we take the verb to be an imperative form. This is not an exceptional example, and other instances can be provided for, especially as nicknames used in chats, forums, etc. : such are for example Dimmitutto 'tell me everything', Fallobene 'make it well', Fammimale 'hurt me', Fammitutto 'make me everything' etc (see also the name Daccibere 'give us to drink' of Giovanni Sercambi's Novelle).

One could of course argue that these formations are some kind of "quotational compounds" (Mathesius (1975: 31), Vachek (1961: 17ff.)) and that as such, they have nothing to do with morphology, given that they arise as (pieces of) syntactic strings. We should keep in mind, however, that there is not clearcut boundary between syntax and morphology, and that many examples can be given of sequences of words progressively loosing their autonomy and (morphological) transparency, and turning into a single (morphologically opaque) word, with phases of oscillation / variation between a sequence $(x)+(y)$ and a single word $(x+y)$. From a syntactic point of view, the internal structure of anthroponymic V-N compounds allows us to identify a head the verbal form - which governs its argument(s). From a semantic point of view, it is clear on the other hand that the referent of these V-N compounds is independent from that of the constituent parts of the compound: nouns like Bevilacqua or Mangiapane do not refer to some kind of water or bread, nor do they refer to the activity of drinking and eating. The state of affairs refered to by the expression at some stage of the designation process isn't anymore available synchronically, though of course it may be reactivated on the basis of the surface relationship that holds between the parts of the compound. The name has conventionalized as pure designation of a given entity, thus occulting the initial motivation underlying the naming process. The nature of the entity in question, thus, cannot be predicted on the basis of the information conveyed by the elements of the compound: to quote Coseriu (1981: 5), the fact that V-N compounds pick up such or such objet or such or such individual is not a matter of langue but a matter of antonomastic designation.

\section{Conclusion}

From the arguments presented above, we are led to the conclusion that we have proposed nothing new: we have suggested that the verbal element of Italian anthroponymic Verb-Noun compounds is an imperative form, a view which has been held by many researchers in the past. What we pointed out, however, is the need first to

\footnotetext{
${ }^{20}$ In lexeme-based morphology, the «lexeme » is taken to be the minimal lexical unit. This unit belongs to one of the major lexical categories and it is an abstract entity : it is uninflected, it is only endowed with a phonological form, with semantic and syntactic (argumental) information. It is clear however that - to take just one example - the formation of Sardinian vocative involves truncation of a surface form, as witnessed (among other things) by metaphonetic alternations (cf. Floricic (2002); see as well the case of Russian neo-vocatives).
} 
re-evaluate the role of semantics: the essential point we are led to is that, due to high frequency, high productivity, and cognitive salience, a given morphological mechanism may apply regardless of the semantic content of some morphological entity. If some Italian anthroponymic Verb-Noun compounds may have arisen as expressive designations describing a recurrent (volitive) state of affairs attached to a given individual, many others are the result of a spreading process of this productive morphological schema. Once rooted in the system, such a productive scheme may apply as a purely morphological mechanism in wider contexts (cf. Lindner (2003) and (2005)).

It should be borne in mind, furthermore, that we referred to the imperative as a morphological base with the property of being minimally specified (i.e. no TAM or voice markers, etc.). However, we shoud remember that, putting aside the case of the truncated monosyllabic imperatives (cf. Huber-Sauter (1951: 51sqq.), Floricic \& Molinu (2003)), Italian imperatives have no specific morphological property, and the category "imperative" does not constitute in Italian a distinct morphological paradigm (cf. Floricic (2007)), but rather a set of forms borrowed from different paradigms, i.e. forms borrowed from the present indicative which, as is well known, is minimally specified. This link between imperative (2sg.) and indicative is particularly clear in such nouns as Faibene, where the verbal element cannot be considered a bare stem, nor a $3^{\text {rd }}$ person of the present indicative. Of course, many other anthroponymic compounds should be taken into account, as should also toponymic, phytonymic and zoonymic compounds, which could yield important information concerning word formation processes and their opacification.

Last, as we saw at the beginning of this contribution, Italian dialects show a great deal of variation at the phonological and syntactic level; needless to say, an exhaustive study of the (anthroponymic) Verb-Noun compounds of dialectal origin would shed new light on the morphological process at work in naming processes. Typological comparison with other Indo-European and non Indo-European languages should also shed light on Italian Verb-Noun compounds. Meillet (1965: 376, §431) mentions in the old Slavic languages the same pattern as the one found in Romance ${ }^{21}$, and Progovac (2006) and (forthcoming) convincingly shows that at least some modern Serbo-Croat V-N compounds show a verbal element which is unequivocally an imperative form ${ }^{22}$ (cf. such compounds as deri-koža 'rip-skin = person who rips you off', jebi-vetar 'fuckwind = charlatan, useless person', podvi-rep 'fold-tail = someone who is crestfallen' or vuci-batina 'pull-whip $=$ tramp, good-for-nothing' $)^{23}$. It is of course outside the scope of this paper to discuss the fundamental idea that any language offers relics of previously active rules and patterns ${ }^{24}$; as pointed out by Klingebiel (1988: 89), "new compounds

\footnotetext{
${ }^{21}$ See as well Brugmann (1888/1972 : II : 86, §47); Darmesteter (1894: 180), Tekavčić (1980: 140ff.), etc.).

${ }^{22}$ Let's point out that many other Serbo-Croatian Verb - Noun compounds show the same indistinctness as that manifested in French, where the verbal form in the $\left(2^{\text {nd }} \mathrm{sg}\right.$.) imperative is syncretic with the $\left(3^{\text {rd }}\right.$ sg.) present indicative (cf. Progovac (2006) and (to appear)).

${ }^{23}$ A few examples can also be found in Russian (cf. perekati-pole 'roll-over-field, tumbleweed', vertihvostka 'wag-tail, a bird', etc.) where they however appear to belong to a closed class of frozen compounds (cf. Progovac (2006) and to appear; Roger Comtet and Sasha Aikhenvald (p.c.)). Vachek (1961: 19) mentions a number of Czech compounds in which the verbal component can be identified as well with the imperative (namely tlučhuba 'braggard', držgrešle 'miser', etc.).

${ }^{24}$ See the following observation of Francescato (1961: 43): «Le système d'une langue est donc, en réalité, le produit de l'entrecroisement de beaucoup de systèmes d'ordre hiérarchique plus limité. Ils peuvent refléter d'un côté les résidus d'un système précédent, de l'autre les premières annonces des tendances actives dans la langue. (...) il est également possible que l'interprétation diachronique des faits
} 
(...) can be formed from older models, just as older syntactic structures may long survive in evolving languages". It is beyond any doubt, however, that historical and typological research on $\mathrm{VN}$ compounds is likely to be rich source of data concerning the nature of the bond between syntax and morphology.

\section{References}

Aebischer, P. (1951), "Preuves anthroponymiques de l'existence du pronom atone $c i$ 'nous' en italien au XIIe siècle”, in Zeitschrift für Romanische Philologie 67. pp.255256

Aikhenvald, A. (to appear), Imperatives and commands. Oxford University Press, Oxford

Aronoff, M. (1994), Morphology by Itself. Cambridge MA: MIT Press.

Bally, C. (1922), «Copule zéro et faits connexes », in Bulletin de la Société de Linguistique de Paris . pp.1-6

Bally, C. (1944), Linguistique générale et linguistique française. A. Francke, Berne

Bauer, L. (1978), «On lexicalization (neither a lexicalist nor a transformationalist be) », in Archivum Linguisticum 9/1 (new series). pp.3-14.

Benvéniste, E. (1966), «Convergences typologiques», in Problèmes de Linguistique Générale 2. Gallimard, Paris. pp.103-112

Bisetto, A. (1999), « Note sui composti VN dell'italiano », in Benincà, P., A. Mioni, \& L. Vanelli (eds.), Fonologia e morfologia dell'italiano e dei dialetti d'Italia. Atti del XXXI Congresso della Società di Linguistica Italiana (Padova, 25-27 settembre 1997). Bulzoni, Roma. pp.503-538

Bisetto, A. \& G. Scalise (1999), « Compounding: morphology and / or syntax? », in Mereu, L. (ed.), The Boundaries of Morphology and Syntax. Benjamins, Amsterdam. pp.31-48.

Botha, R. (1983), Morphological Mechanisms. Pergamon Press, Oxford.

Boucherie, A. (1876), Review of Darmesteter A. (1894), Traité de la formation des mots composés dans la langue française comparée aux autres langues romanes et au latin. Emile Bouillon, Paris ; Meunier L.-F. (1875) Les composés qui contiennent un verbe à un mode personnel. Librairie Durand et Pedone-Lauriel, Paris. in Revue des Langues Romanes 2. pp.264-275

Bréal, M. (1897), Essai de sémantique (science des significations). Hachette, Paris

Brøndal, V. (1943), Essais de linguistique générale. Einar Munksgaard, Copenhague

Brøndal, V. (1948), Les parties du discours. Partes orationis : Etudes sur les catégories linguistiques. Einar Munksgaard, Copenhague

Brugmann, K. (1888), A Comparative Grammar of the Indo-Germanic Languages. 5 vol. 2nd reprint 1972. Varanasi, India: Chowkhamba Sanskrit Series Office

Brugmann; K. (1900), « Über das wesen der sogenannten wortzusammensetzung. Eine sprachpsychologische studie », in Berichte über die Verhandlungen der königlich sächsischen Gesellschaft der Wissenschaften zu Leipzig 52. pp.359-401

de la langue éclaircisse la structure du système dans sa totalité, c'est-à-dire la coexistence des systèmes partiels dans le système total. »

«A language system is thus, in fact, the result of the crossing of many systems hierarchically more limited. They may reflect on one side the relics of a previous system, on the other the premises of active tendencies of language. (...) it is as well possible that the interpretation of diachronic facts of language shed a new light on the overall structure of the system, that is the coexistence of partial systems in the total system." 
Brugmann, K. (1905), Abrégé de grammaire comparée des langues indoeuropéennes (trad. sous la dir. de A. Meillet et R. Gauthiot). Klincksieck, Paris

Butet, P. R. F. (1801), Abrégé d'un cours complet de lexicologie, à l'usage des élèves de la quatrième classe de l'École Polymathique. Crapelet, Paris

Bybee, J. L. (1985). Morphology: A study of the relation between meaning and form. Amsterdam: John Benjamins.

Bybee J. L. \& Brewer M. A. (1980), «Explanation in morphophonemics: changes in provençal and spanish preterite forms», in Lingua 52, n³-4. pp.201-242

Castellani, A. (1956), «Nomi fiorentini del Dugento», in Zeitschrift für Romanische Philologie 72. pp.54-87

Colón Doménech, G. (2002), «Nebrija y los sustantivos románicos de doble imperativo", in Para la historia del léxico español. Vol. II. Arco / Libros, Madrid. pp.468-494

Corbin, D. (1992), «Hypothèses sur les frontières de la composition nominale », in Cahiers de grammaire 17. pp. 26-55

Corbin, D. (1997), «Locutions, composés, unités polylexématiques : lexicalisation et mode de construction », in La locution, entre langue et usages, M. Martins-Baltar (éd.), Fontenay-St-Cloud, ENS Editions. pp. 55-102

Coseriu, E. (1962), «El plural en los nombres propios », in Teoria del lenguaje y lingüistica general. Editorial Gredos, Madrid. pp.261-281

Coseriu, E. (1981), «Les procédés sémantiques dans la formation des mots », in Cahiers Ferdinand de Saussure 35. pp.3-16

Creissels, D. (1995), Eléments de Syntaxe Générale. Presses Universitaires de France, Paris

Daneš, F. (1966), "The Relation of Centre and Periphery as a Language Universal », in Vachek J. (ed.), Les problèmes du Centre et de la Périphérie du Système de la Langue. Prague, Academia / Paris, Klincksieck (Travaux Linguistiques de Prague 2). pp.9-21

Daneš, F. (1971), «On linguistic Strata (levels)», in Etudes de la phonologie, typologie et de la linguistique générale. Prague, Academia / Paris, Klincksieck (Travaux Linguistiques de Prague 4). pp.127-143

Darmesteter, A. (1877), De la création actuelle de mots nouveaux dans la langue française et des lois qui la régissent.

Darmesteter, A. (1894), Traité de la formation des mots composés dans la langue française comparée aux autres langues romanes et au latin. Emile Bouillon, Paris

Denina, C. (1803), «Sur l'origine des noms des nations, des pays, des rivières, des villes et des familles ", in Mémoires de l'Académie Royale des Sciences et BellesLettres. pp.41-71

Destutt de Tracy (1814), Eléments d'idéologie. Première partie: Idéologie proprement dite. Vrin, Paris

Diez, F. (1874), Grammaire des langues romanes, vol.2. A. Francke, Paris

Dokulil, M. (1994) [1958]: «On Morphological Oppositions», in: P. A. Luelsdorff, J. Panenová \& P. Sgall (eds.), Praguiana 1945-1990, John Benjamins: Amsterdam / Philadelphia. pp.113-130

De Felice, E. (1987), « Onomastica », in Lazzeroni (ed.), Linguistica storica. NIS, Roma. pp.147-179

Fanfani, P. (1864), Vocabolario dell'uso toscano, Firenze

Federici, V. (1907), Regesta Chartarum Italiae. Regesto di S. Appollinare Nuovo. Ermanno Loescher: Roma. 
Filzi M. (1914), « Contributo alla sintassi dei dialetti italiani », in Studj Romanzi 11. pp.5-92

Flechia, G. (1877-78), « Di alcuni criteri per l'originazione de' cognomi italiani », in Atti della Reale Accademia dei Lincei, Anno CCLXXV, serie terza. (Memorie della classe di scienze morali, storiche e filologiche). pp.609-621

Flechia, G. (1879), « Review of Le accorciature dei nomi propri italiani, raccolte da Pietro Fanfani. Libretto per le scuole. Firenze, $1878 »$, in Rivista di Filologia e d'Istruzione Classica 7. pp.375-394

Flechia, G. (1903), « Note lessicali ed onomatologiche di Giovanni Flechia », in Studj di Filologia Romanza 9. pp.693-706

Floricic, F. (2000), «De l'impératif italien sii et de l'impératif en général », in Bulletin de la Société de Linguistique de Paris, t.XCV, fasc.1. pp.227-266

Floricic, F. (2002), «La morphologie du Vocatif: l'exemple du sarde », in Vox Romanica 61. pp.151-177

Floricic, F. (2003), «Réflexions sur l'alternance qualcosa / qualche cosa "quelque chose" en italien », in Cahiers de Grammaire 28. pp.135-151

Floricic, F. (2007), «Les impératifs italiens entre verbe et interjection », in Echo des Etudes Romanes III-1/2. pp.71-92

Floricic, F. \& Molinu, L. (2003), «Imperativi 'monosillabici' e "Minimal Word" in italiano 'standard' e in sardo ", in Actes du XXXV Congresso internazionale di Studi della SLI (Società di Linguistica Italiana). "Il verbo italiano - Approcci diacronici, sincronici, contrastivi e didattici" (Paris, 20 - 22 septembre 2001). pp.343-357

Francescato, G. (1961), «Systèmes coexistants ou systèmes diachroniques », in Neophilologus 45 (1). pp.37-44

Graffi, G. (1996), «Alcune riflessioni sugli imperativi italiani », in Benincà P., G. Cinque, T. de Mauro \& N. Vincent (eds.), Italiano e dialetti nel tempo. Saggi di grammatica per Giulio C. Lepschy. Bulzoni, Roma. pp.133-148

De La Grasserie, R. (1907), Du langage subjectif, biologique ou émotionnel \& sociologique ou révérentiel, opposé au langage psychologique de la pensée. Ernest leroux, Paris

Guyojeannin, O. (1994), «L'onomastique émilienne $\left(\mathrm{XI}^{\mathrm{e}}\right.$, milieu XIII ${ }^{\mathrm{e}}$ siècle). Le cas de Reggio Emilia d'après le fonds de San Prospero », in Mélanges de l'école française de Rome 106/2. pp.381-446.

Haspelmath, M. (2006), «Against markedness (and what to replace it with)», in Journal of Linguistics 42/1. pp.25-70

Hjelmslev, L. (1985) [1933], «Structure générale des corrélations linguistiques», in: Nouveaux essais. Presses Universitaires de France : Paris. pp.25-66

Hjelmslev, L. (1972) [1935]: La catégorie des cas. Étude de grammaire générale. München (Internationale Bibliothek für Allgemeine Linguistik 25) 344

Hockett, C. (1947), «Problems of morphemic analysis », in Language 23/4. pp.321-

Huber-Sauter, M. (1951), Zur Syntax des Imperativs im Italienischen. Bern: Francke (Romanica Helvetica. Ser. linguistica 36)

Ilie, D. (1983), «La place des noms propres dans le système de la langue », in Cahiers d'Etudes Romanes 8. pp.165-177

Jakobson, R. (1990) [1936], «Contribution to the General Theory of Case», in: L. R. Waugh \& M. Monville-Burston (eds.), On Language. Roman Jakobson. Harward University Press: Cambridge (USA) / London. pp.332-385

Kenesei, I. (2007), «Semiwords and Affixoids: The territory between word and Affix », in Acta Linguistica Hungarica 54. pp.263-293. 
Kerleroux, F. (2004), «Sur quels objets portent les opérations morphologiques de construction? », in Lexique 16. La formation des mots : horizons actuels. pp.85-123

Klingebiel, K. (1988), «New compounds from the old: an unexpected source of verb + noun compounds in Romance ", in Axmaker, S., A. Jaisser \& H. Singmaster (eds.), Proceedings of the Fourteenth Annual Meeting (February 13-15, 1988). General session and parasession on grammaticalization. Berkeley Linguistic Society, Berkeley. pp.88-99 (Berkeley Linguistic Society 14)

Koch, H. (1995), « The creation of morphological zeroes », in Booij, G. \& J. van Marle (eds.), Yearbook of Morphology 1994. Kluwer Academic Publishers: Dordrecht. pp.31-71.

Koenig, F. (1953), « Notes on Spanish Word Formation », in Modern Language Notes 68/1. pp.13-17

Kreutzer K. (1967), Der typus Guardavalle (Schauinsland) in den romanischen Sprachen. Tübingen

Kruszewski, M. (1883/1995), "Outline of linguistic science », in Writings in general linguistics. John Benjamins, Amsterdam / Philadelphia. pp. 34-178

Kuryłowicz, J. (1956), «La position linguistique du nom propre », in Esquisses Linguistiques I. Wilhelm Fink Verlag, München 1973. pp.182-192

Kuryłowicz, J. (1964), The Inflectional Categories of Indo-European. Carl Winter, Heidelberg

Kuryłowicz, J. (1965), «The evolution of grammatical categories », in Esquisses Linguistiques II. Wilhelm Fink Verlag, München 1975. pp.38-54

Kuryłowicz J. (1966-67), «Sur une particularité de la conjugaison slave», in Esquisses Linguistiques II. Wilhelm Fink Verlag, München. pp.470-474

Kuryłowicz, J. (1968), «The Notion of Morpho(pho)neme», in Lehmann W. P. \& Y. Malkiel (eds.), Directions for Historical Linguistics: A Symposium. University of Texas Press: Austin. pp.65-82

Kuryłowicz J. (1977), Problèmes de linguistique indo-européenne. Prace Językoznawcze 90. Polska Akademia Nauk, Wrocław / Warszawa / Kraków / Gdańsk

Lapointe, S. (1980), A Theory of Grammatical Agreement. University of Massachusetts, Amherst

Lehmann, C. (2002), Thoughts on Grammaticalization. ( $2^{\mathrm{d}}$ edition). Erfurt (Arbeitspapiere des Seminars für Sprachwissenschaft der Universität Erfurt 9)

Lehmann, C. (2004), "Theory and method in grammaticalization », in Zeitschrift für Germanistische Linguistik 32/2. pp.152-187

Lemaréchal, A. (1997), Zéro(s). Presses Universitaires de France, Paris

Lindberg, L. (1898), Les locutions verbales figées dans la langue française. Almqvist \& Wiksell, Upsal

Lindner, T. (2003), « Aspekte der lateinisch-romanischen Kompositaforschung », in Moderne Sprachen 47. pp.115-141

Lindner, T. (2005), « Nominalkomposition im vulgärlatein und frühromanischen, sowie ein plädoyer für die imperativthese », in Schweiger, G. (ed.), Indogermanica. Festschrift Gert Klingenschmitt. Indische, Iranische und Indogermanische Studien dem Verehrten Jubilar Dargebracht zu seinen fünfundsechzigsten Geburtstag. Taimering. Schweiger Vwt-Verlag. pp.377-387

Lloyd, P. M. (1966), «A possible structural factor in the development of VerbComplement compounds in the Romance languages », in Studia Neophilologica 38/2. pp.257-262

Maiden, M. (1998), Storia linguistica dell'Italiano. Bologna. Il Mulino 
Maiden, M. (2007), "On the morphology of Italo-Romance Imperatives », in Bentley, D. \& A. Ledgeway (eds.), Sui dialetti italoromanzi. Saggi in onore di Nigel B. Vincent. The Italianist. pp.148-164

Mańczak, W. (1963), «Tendances générales du développement morphologique», in Lingua 12/1. pp.19-38

Mańczak, W. (1970), «Sur la théorie des catégories 'marquées' et 'non marquées' de Greenberg », in Linguistics 59. pp.29-36

Mańczak, W. (1995), «Morphologie des noms: Règles de flexion, systèmes de flexion », in Eichler, E., G. Hilty, H. Löffler, H. Steger \& L. Zgusta (eds.), An International Handbook of Onomastics / Manuel international d'onomastique / Ein internationales Handbuch zur Onomastik. Berlin / New York: Walter de Gruyter. pp.427-431

Mańczak, W. (2004), «Certaines formes de l'impératif en italien et en sarde », in M. Świątkowska, R. Sosnowski \& I. Piechnik (eds.), Maestro e Amico. Miscellanea in onore di Stanisław Widłak. Mistrz i Przyjaciel. Studia dedykowane Stanisławowi Widłakowi. Wydawnictwo UJ, Kraków. pp.231-234

Mańczak, W. (2008), Linguistique générale et linguistique indo-européenne. Polska Akademia Umiejętności, Wydzial Filologiczny, Kraków

Marcato, C. (1996), «Morphologie et formation des mots des plus anciens noms de personnes : domaine roman », in Eichler E., G. Hilty, H. Löffler, H. Steger \& L. Zgusta (eds.), Namenforschung / Name Studies / Les noms propres. Tome 2. Berlin / New York, De Gruyter. pp.1187-1193

Mathesius, V. (1975), A Functional Analysis of Present Day English on a General Linguistic Basis. The Hague, Mouton \& Co.

Meillet, A. (1921), " Convergence des développements linguistiques », in Linguistique historique et linguistique générale, Paris. pp.61-75 [ $\left.{ }^{1} 1918\right]$

Meillet, A. (1965), Le slave commun. Honoré Champion, Paris

Meillet, A. (1995), Pour un manuel de linguistique générale. Edizione di manoscritti inediti conservati al Collège de France raccolti e pubblicati a cura di Fiorenza Granucci, Roma (Atti della Accademia Nazionale dei Lincei, Anno CCCXCII, Memorie, Serie IX, Vol.VI, fasc.1)

Meunier, L. F. (1875). Les composés qui contiennent un verbe à un mode personnel en français, en italien et en espagnol. Paris, Imprimerie nationale.

Meyer-Lübke W. (1895), Grammaire des langues romanes. Tome II: Morphologie. (trad. Doutrepont A. et G.). H. Welter, Paris.

Migliorini, B. (1927), Dal nome proprio al nome comune. Studi semantici sul mutamento dei nomi propri di persona in nomi comuni negl'idiomi romanzi. Genève

Migliorini, B. (1957), Saggi linguistici. Firenze, Le Monnier

Muratori, L. (1837), Dissertazioni sopra le antichità italiane. Dissertazione XLI: Dei nomi e soprannomi degli Antichi. Dissertazione XLII: Dell'origine de' Cognomi. Milano, Società tipografica dei classici italiani.

Nannucci, V. (1843), Analisi critica dei verbi italiani investigati nella loro primitiva origine. Le Monnier, Firenze

Napoli, D. J. \& I. Vogel (1990), “The Conjugations of Italian”, in Italica 67/4. pp.479-502

Nielsen, B. (2002), «The morphology and semantics of agentive synthetic compounds in English and Romance », in Nowak E. (ed.), Morphology in comparison. Arbeitspapiere zur Linguistik 37 (Technische Universität Berlin). pp.70-101 
Pagliaro, A. (1993), Opere. Storia della linguistica. Tomo primo. Sommario di linguistica ario-europea. Ristampa anastatica dell'edizione del 1930. Novecento, Palermo

Paul, H. (1891), Principles of the history of language. London: Longmans, Green \& Co. (Translation of Prinzipien der Sprachgeschichte, Niemeyer, Halle, by H. A. Strong)

Paulis, G. (1997), «Di alcuni soprannomi sardi medioevali », in Studi sul Sardo Medioevale. Nuoro: Ilisso Edizioni. pp.167-169

Pieri, S. (1913), «Appunti toponomastici », in Studj Romanzi 10. pp.105-122

Pisani, V. (1933), «Pānini, Māgha e l'imperativo descrittivo », in Rendiconti della Reale Accademia Nazionale die Lincei. Classe di scienze morali, storiche e filologiche. Serie sesta, Vol.9. pp.246-267

Poma, C. (1910), Il composto verbale nella onomastica italiana : appunti filologici. Tip. S. Giuseppe dgli Artigianelli, Torino

Poma, C. (1914), Cognomi italiani formati da verbi che indicano azione. Lapi, Città di Castello

Pott, A. F. (1859), Die Personennamen, insbesondere die Familiennamen und ihre Entstehungsarten unter Berücksichtigung der Ortsnamen. Brockhaus, Leipzig

Prati A. (1931), «Composti imperativi quali casati e soprannomi », in Revue de Linguistique Romane 7/27-28. pp.250-262

Prati A. (1958), «Nomi composti con verbi », in Revue de Linguistique Romane 22/85-86. pp.98-119

Progovac, L. (2006) «Fossilized Imperative in Compounds and Other Expressions », in Online Proceedings of the First Inaugural Meeting of SLS (Slavic Linguistics Society). Bloomington, IN.

Progovac, L. (forthcoming), «Exocentric Compounds: From Evolution to Extinction»

Radimský, J. (2006), Les composés italiens actuels. Cellule de Recherche en Linguistique, Paris

Rainer, F. (2001), « Compositionality and paradigmatically determined allomorphy in Italian word-formation », in Schaner-Wolles C., Rennison J. \& Neubarth F. (eds.), Naturally! Linguistic studies in honour of Wolfgang Dressler presented on the occasion of his $60^{\text {th }}$ birthday. Rosenberg \& Sellier, Torino. pp.383-392

Ralli, A. (2008), «Compound markers and parametric variation », in Language Typology and Universals 61/1. pp.19-38

Ricca, D. (2005), «Al limite tra sintassi e morfologia : i composti aggettivali V-N nell'italiano contemporaneo », in Grossmann, M. \& A. M. Thornton (eds.), La formazione delle parole. Atti del XXXVII Congresso Internazionale di Studi della Società di Linguistica Italiana (L'Aquila, 25-27 settembre 2003). Bulzoni, Roma. pp.465-486

Ricca, D. (2008), «VN compounds in Italian: Data from corpora and theoretical issues », paper read at CompoNet Congress on Compounding (Bologna, 6-7/06/2008)

Rohlfs, G. (1969), Grammatica storica della lingua italiana e dei suoi dialetti. Sintassi e formazione delle parole. Einaudi, Torino (Piccola Biblioteca Einaudi 150)

Rohlfs, G. (1972), «Origine e fonti dei cognomi in Italia », in Studi e ricerche su lingua e dialetti d'Italia. Sansoni, Milano. pp.109-121

Salvioni C. (1899), "Giunte italiane alla Romanische formenlehre di W. MeyerLuebke », in Studj di Filologia Romanza 7. pp.183-239

Santini, P. (1895), Documenti dell'antica costituzione del comune di Firenze. G. P. Vieusseux, Firenze. 
Sauer, H. (2004), «Lexicalization and demotivation », in Booij G., C. Lehmann, J. Mugdan \& S. Skopeteas (eds.), Morphologie / Morphology. Ein internationales Handbuch zur Flexion und Wortbildung. 2. Halbband. Berlin / New York, Walter de Gruyter. pp.1625-1636.

Schulze, C. (1868), «Imperativisch gebildete substantiva», in Archiv für das Studium der Neueren Sprachen und Literaturen 23/43. pp.13-40

Skok, P. (1911), «Die verbalkomposition in der romanischen Toponomastik », in Prinzipienfragen der Romanischen Sprachwissenschaft. Teil II. Max Niemeyer, Halle. (Beihefte zur Zeitschrift für Romanische Philologie 27)

Spagnoletti, C. \& Dominicy, M. (1992), «L'accent italien et la cliticisation de la terminaison verbale no », in Revue Québécoise de Linguistique 21. pp.9-31

Stefanelli, R. (1998-99), « Su alcuni composti esocentrici dell'italiano: il tipo V + V (saliscendi, andirivieni, fuggifuggi) », in Quaderni del Dipartimento di Linguistica (Università di Firenze) 9. pp.31-47

Štekauer, P. (1999), «Fundamental principles of an onomasiological theory of word-formation in English », in Brno Studies in English 25. pp.75-98

Štekauer, P. (2002), "On the theory of neologisms and nonce-formations », in Australian Journal of Linguistics 22/1. pp.97-112

Szemerényi, O. (1977), «Studies in the kinship terminology of the Indo-European Languages, with special reference to Indian, Iranian, Greek and Latin », in Acta Iranica 16 , pp. $1-240$

Tekavčić, P. (1980), Grammatica storica dell'italiano. II. Morfosintassi, III. Lessico. Il Mulino, Bologna

Tesnière, L. (1988), Eléments de syntaxe structurale. Klincksieck, Paris

Thornton, A. M. (1990), «Sui deverbali italiani in -mento e -zione (I) », in Archivio Glottologico Italiano 75(2). pp. 169-206.

Thornton, A. M. (1991), « Sui deverbali italiani in -mento e -zione (II) », in Archivio Glottologico Italiano 76(1). pp. 79-102.

Thornton, A. M. (1999), «Diagrammaticità, uniformità di codifica e morfomicità nella flessione verbale italiana », in Benincà, P., A. Mioni, \& L. Vanelli (eds.), Fonologia e morfologia dell'italiano e dei dialetti d'Italia. Atti del XXXI Congresso della Società di Linguistica Italiana (Padova, 25-27 settembre 1997). Bulzoni, Roma. pp.483-502

Thornton, A. M. (2007), "Phénomènes de réduction en italien », in DelaisRoussarie E. \& L. Labrune (eds.), Des sons et des sens. Données et modèles en phonologie et en morphologie. Lavoisier, Paris. pp.241-268

Vachek, J. (1961), «Some less familiar aspects of the analytical trend of english », in Brno Studies in English 3. pp.9-74

Villoing, F., (2000), «Les principes de la morphologie dans la grammaire comparée du XIXè siècle : le témoignage des mots composés du type $[\mathrm{VN}]_{\mathrm{N}}$, in Moderne Sprachen 44, Edition Praesens, Salzburg : 107-134.

Villoing, F., (2003a), «Les mots composés VN du français : arguments en faveur d'une construction morphologique », Cahiers de Grammaire 28. pp. 183-196

Villoing, F. (2003b), Les mots composés $[V N]_{N / A} d u$ français: réflexions épistémologiques et propositions d'analyse. Thèse de l'Université de Paris 10

Vogel, I. (1993), «Verbs in Italian morphology », in Yearbook of Morphology 6. 219-254

Vogel, I. \& D. J. Napoli (1995), « The verbal component in Italian compounds », in Jon Amastae, Grant Goodall and Mario Montalbetti (eds.) Proceedings of The 
Linguistics Symposium on Romance Languages. XXII. Philadelphia: John Benjamins. 367-381.

Waugh, L. R. (1982), «Marked and unmarked: a choice between unequals in semiotic structure », in Semiotica 38/3-4. pp.299-318

Wegener, P. (1885/1971), The life of speech. Charlottesville, The University Press of Virginia (translation of Untersuchungen ueber die Grundfragen des Sprachlebens)

Zamboni, A. (1989), « Premesse morfologiche e tipologiche del composto italiano capinera, pettirosso", in Monica Berretta, Piera Molinelli \& Ada Valentini (eds.), Parallela 4. Morfologia / Morphologie. Atti del $V^{\circ}$ Incontro Italo-Austriaco della Società di Linguistica Italiana a Bergamo (2-4 ottobre 1989) / Akten des 5. österreichisch-Italienischen Linguistentreffens in Bergamo (2-4 Oktober 1989). Gunter Narr: Tübingen.

Žirmunskij, V. M. (1966), «The word and its bounderies », in Linguistics 27. pp.65-91 